\title{
FRACTURE EVOLUTION IN SOLUBLE ROCKS: FROM SINGLE-MATERIAL FRACTURES TOWARDS MULTI-MATERIAL FRACTURES
}

\author{
ODVISNOST KRAŠKEGA RAZVOJA RAZPOKE OD VRSTE IN \\ ZAPOREDJA VODOTOPNIH KAMNIN, SKOZI KATERE POTEKA
}

\author{
Georg KAUFMANN ${ }^{*}$, Franci GABROVŠEK ${ }^{2} \&$ Douchko ROMANOV $3^{3^{*}}$
}

\begin{abstract}
UDC 551.435.8

Georg Kaufmann, Franci Gabrovšek \& Douchko Romanov: Fracture evolution in soluble rocks: From single-material fractures towards multi-material fractures

We employ a numerical model describing the evolution of secondary porosity in a single fracture embedded in soluble rock (limestone, gypsum, and anhydrite) to study the evolution of isolated fractures in different rock types. Our main focus is three-fold: The identification of shallow versus deep flow paths and their evolution for different rock types; the effect of precipitation of the dissolved material in the fracture; and finally the complication of fracture enlargement in fractures composed of several different soluble materials. Our results show that the evolution of fractures composed of limestone and gypsum is comparable, but the evolution time scale is drastically different. For anhydrite, owing to its difference from calcite in the kinetical rate law describing the removal of soluble rock, the evolution is even faster. Precipitation of the dissolved rock due to changes in the hydrochemical conditions can clog fractures fairly fast, thus changing the pattern of preferential pathways in the soluble aquifer, especially with depth. Finally, limestone fractures coated with gypsum, as occasionally observed in caves, will result in a substantial increase in fracture enlargement with time, thus giving these fractures a hydraulic advantage over pure limestone fractures in their competition for capturing flow.
\end{abstract}

Key words: soluble rock, single fracture, dissolution and precipitation, inception horizon.

\author{
Izvleček UDK 551.435 .8 \\ Georg Kaufmann, Franci Gabrovšek \& Douchko Romanov: \\ Odvisnost kraškega razvoja razpoke od vrste in zaporedja \\ vodotopnih kamnin, skozi katere poteka
}

$\mathrm{Z}$ numeričnim modelom smo raziskovali razvoj sekundarne poroznosti $\mathrm{v}$ enodimenzionalni razpoki $\mathrm{v}$ apnencu, sadri in anhidridu. Cilji raziskav so bili: 1) ugotoviti razlike med razvojem plitvih in globokih razpok v različnih kamninah; 2) oceniti učinek morebitnega izločanja enega od mineralov v razpoki in 3) dinamika rasti razpoke, ki gre skozi plasti različnih kamnin. Rezultati kažejo na primerljiv razvoj razpok v apnencu in sadri, pri čemer je čas razvoja v obeh kamninah precej različen. $\mathrm{V}$ anhidridu je zaradi drugačne kinetike raztapljanja razvoj še hitrejši. Izločanje ob spreminjajočih se geokemičnih pogojih lahko hitro zamaši razpoke in posebej v večjih globinah spremeni poti razvoja mreže kraških prevodnikov. V primeru, ko so razpoke $\mathrm{v}$ apnencu prekrite s plastjo sadre, kar v naravi pogosto opažamo, je hitrost širjenja najhitrejša, kar daje vodnim potem vzdolž takih razpok izrazito primerjalno prednost pri zajemanju razpoložljivega toka.

Ključne besede: vodotopne kamnine, enostavna razpoka, raztapljanje in izločanje, incepcijski horizont.

\footnotetext{
${ }^{1}$ Institute of Geological Sciences, Geophysics Section, Freie Universität Berlin, Malteserstr. 74-100, Haus D, 12249 Berlin, Germany, e-mail: georg.kaufmann@fu-berlin.de

${ }^{2}$ Karst Research Institute ZRC SAZU, Postojna, Slovenia, e-mail: gabrovsek@zrc-sazu.si

${ }^{3}$ Institute of Geological Sciences, Geophysics Section, Freie Universität Berlin, Malteserstr. 74-100, Haus D, 12249 Berlin, Germany, e-mail: douchko.romanov@fu-berlin.de

${ }^{*}$ Corresponding Author
}

Received/Prejeto: 10.05.2017 


\section{INTRODUCTION}

Soluble rocks such as limestone, dolostone, gypsum, and anhydrite are characterised by the dissolution of material by water, often enriched with carbon dioxide, sulphides or other organic acids. Removal occurs both on the rock surface and along fractures and faults in the subsurface in the case of a telogenetic evolution of the rock. While in insoluble rocks the permeability given by the continuous subsurface flow paths between interconnected fractures and bedding planes remains mainly constant, in soluble fractured aquifers permeability increases substantially with time. The resulting flow paths in soluble fractured aquifers provide efficient drainage paths for water, and surface flow often completely disappears, as the enlarged fractures can accommodate large amounts of water, even during larger recharge events. The subsurface flow paths are, however, preferentially developed, and often voids enlarged to the meter size and more provide access to caves carrying entire underground rivers.

We focus on chemical reactions during the evolution of a fracture in soluble rocks by comparing different rock types (limestone, gypsum, anhydrite). For this purpose, we simplify our fracture to a single, isolated circular conduit with variable diameter, through which flow is driven either under laminar or turbulent flow conditions, with a conduit roughness coefficient mimicking small-scale wall irregularities, and transport of dissolved species as an advective process. The interaction of this single isolated conduit with other conduits in the aquifer is therefore neglected.
Szymczak et al. (2006; 2009; 2011) have emphasized that a single fracture modelled in two dimensions will lead to a break-up of the dissolution front, inducing finger flow and a preferential enlargement along the twodimensional fracture. Thus, the two-dimensional fracture will evolve more rapidly than its one-dimensional analogon. However, this behaviour, termed exchange flow between fractures in a karst aquifer, has been studied extensively in the past, and we will argue that the effect of exchange flow will be similar in all chosen rock types and thus is already understood.

In this paper, we address three key points: (i) Discuss shallow and deep flow and evolution in fractures for different soluble rock types (limestone, gypsum, anhydrite), (ii) include precipitation into the evolution of the fractures, (iii) discuss the evolution of fractures composed of several soluble rock layers.

We have organised the paper as follows: In section 2 , we discuss processes controlling the evolution of conduits, which we want to address by our numerical modelling. In section 3, we introduce physical and chemical principles for flow and evolution of a single conduit embedded in soluble rock. In section 4 , we discuss the modelling results, starting with the enlargement of single conduits in limestone, gypsum and anhydrite in shallow and deep conditions. We then proceed to describe changes due to possible precipitation of the soluble rock. We finally look at conduits composed of several soluble rock types. In section 5, we discuss and summarise our results.

\section{PROCESSES}

In this section, we discuss mechanisms for fracture widening, fracture clogging, and the interaction of different dissolved species in fractures. Fracture enlargement in soluble rocks is not a uniform process, but highly selective.

The evolution of caves with respect to the water table was a debated phenomena in the mid- $20^{\text {th }}$ century, largely made upon hydrogeological principles. Ford and Ewers (1978) have reconciled these principles with the definition of the four-state model: In this model, fracture spacing controls the type of cave evolution. For low fracture spacing, caves with deep phreatic loops can evolve, higher fracture spacing facilitates evolution of caves along the water table. The four-state model is capable of explaining cave geometries for different geological settings, such as the evolution of caves along the water table, if fracture spacing is dense, and the evolution of deep bathy-phreatic cave loops, if the fracture spacing is less dense.

Worthington (2001) came up with a different explanation of deep phreatic flow paths: Viscosity decreases with increasing temperature, thus with depth, and therefore flow deeper in the aquifer can have a slight hydraulic advantage over shallow flow (hydraulic control). Kaufmann et al. (2014), however, have shown by means of numerical modelling that the flow enhancement due to the decrease in viscosity with depth (hydraulic control) is counteracted by the reduction of solubility with depth (chemical control) and the reduction of initial fracture width with depth due to lithostatic pressure (structural control). 
Recently, the hypothesis of inception horizons (e.g. Lowe 1992, 2000; Filipponi \& Jeannin 2006; Filipponi et al. 2009) extended the idea of preferential enlargement of fractures and bedding planes. In this hypothesis, an inception horizon is identified as part of the soluble rock, which has different physical, lithological or chemical properties than the surrounding rock. Often, inception horizons identified in the field are covered with gypsum. We will explore the evolution of a single conduit in limestone coated with gypsum to explore the importance of chemical control in conduit evolution, beside the hydraulic control described by the four-state model.

The clogging of fractures can also play a key role in the development of flow through aquifers. Beside clogging through sediments, large lithostatic pressure, or bacterial activity, soluble rocks can in places deliver solution supersaturated with a mineral species, which then starts to precipitate and reduce fracture width and thus flow. As an example, we report the failed geothermal drill holes in Staufen (Breisgau, Germany), where the conversion of anhydrite to gypsum, once the anhydrite came into contact with water, caused widespread damage. In 2007, seven boreholes for geothermal heat exchange were drilled in the city of Staufen to a depth of 140 m (e.g. Sass \& Burbaum 2010; Lubitz et al. 2013). One borehole connected two independent groundwater horizons and flow through an intermittent anhydrite lens caused widespread dissolution of the anhydrite and subsequent precipitation of gypsum. The larger volume of the precipitated gypsum caused surface uplift of up to $1 \mathrm{~cm} /$ month in an area $100 \times 150 \mathrm{~m}$, which caused widespread structural damage to the historical buildings. We will explore the interaction between anhydrite-gypsum in a single fracture.

\section{MODELLING FLOW AND EVOLUTION}

The evolution of fractures in soluble rock is controlled by both flow through the fracture and changes of the geometry of the fracture due to dissolution of and precipitation on the fracture walls. These two groups of properties, which we term hydraulic properties and chemical properties, are coupled, and this coupling often results in a feedback mechanism responsible for the preferential enlargement of fractures and bedding partings in soluble rock.

In this section, we collect the relevant relations needed to describe and understand this feedback between hydraulic and chemical processes. We will use the mathematical concept of a circular conduit to mimic the real fracture. In Fig. 1, a typical cross section $3 \mathrm{~km}$ long and $2 \mathrm{~km}$ deep for such a conduit is outlined: Two conduit paths are shown (white with black outline): one flow path close to the surface along the water table, the other flow path resembling bathyphreatic conditions and reaching into zones, where properties such as temperature, pressure and related parameters differ substantially from their surface values.

\section{HYDRAULIC PROPERTIES}

We start by defining a circular conduit of diameter $d[\mathrm{~m}]$ and length $l[\mathrm{~m}]$, and the deepest point of the conduit as $\mathrm{z}_{\max }[\mathrm{m}]$. Flow through this conduit can be described in general by the Navier-Stokes equations, which in our case can be simplified to classical Darcy flow under laminar or turbulent conditions (e.g. Beek \& Muttzall 1975):

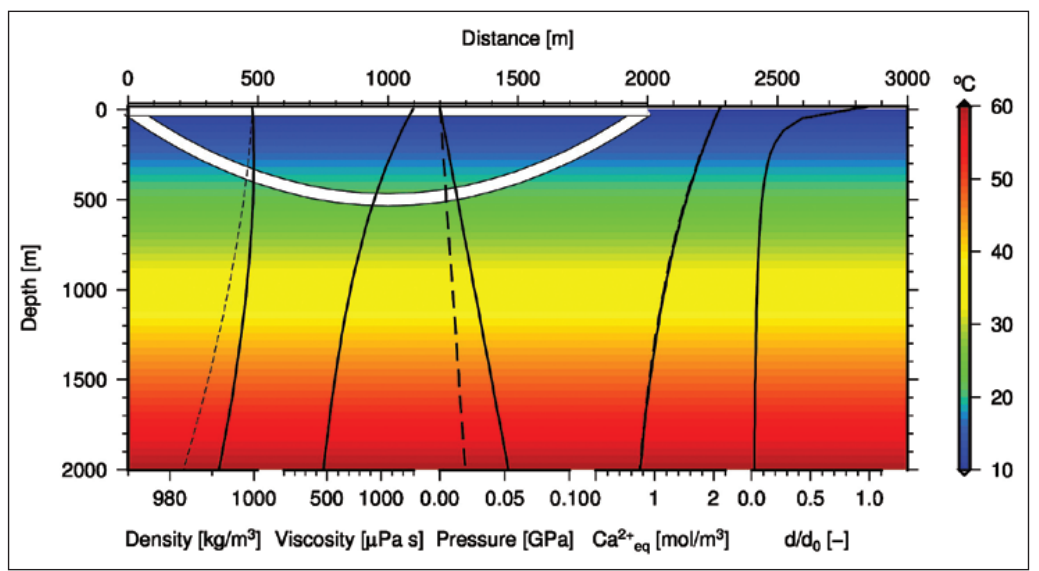

Fig. 1: Model setup for the karst conduit evolution. Temperature is shown as color contours, ranging from $10{ }^{\circ} \mathrm{C}$ at the surface to around $60{ }^{\circ} \mathrm{C}$ in $2 \mathrm{~km}$ depth. The corresponding properties of water are shown as black lines: density $\rho$ (dashed line temperature effect only; solid line temperature and pressure effect), viscosity $\eta$, pressure $p$ (dashed line water pressure, solid line lithostatic pressure), calcium equilibrium concentration ceq (dashed line temperature effect only, solid line temperature and pressure effect; not distinguishable), fracture-depth relation $d / d i$. The thick white lines with black outline indicate two conduit paths, one along the water table, one deep bathyphreatic cave. 
$Q=\sqrt{\frac{\pi^{2} g d^{5}}{8 f l} \Delta h}$,

with $Q\left[\mathrm{~m}^{3} / \mathrm{s}\right]$ the flow rate through the fracture, $\Delta h[\mathrm{~m}]$ the drop in hydraulic head between both ends of the fracture, $g\left[\mathrm{~m} / \mathrm{s}^{2}\right]$ gravitational acceleration, and $f[-]$ the friction factor. Note that (1) is a reformulation of the classical Poiseuille law for both laminar and turbulent conditions.

The friction factor can be defined as (e.g. Jeppson 1976):

$$
f=\left\{\begin{array}{c}
f_{l}=\frac{64}{R e}, R e \leq R e_{c} \\
f_{s}=0.3164 R e^{-0.25}, R e>R e_{c} \\
f_{t}^{-0.5}=1.14-2 \log \left(\frac{w}{d}+\frac{9.35}{R e} f_{t}^{-0.5}\right), R e>R e_{c} \\
f_{r}^{-0.5}=1.14-2 \log \left(\frac{w}{d}\right), R e>R e_{c}
\end{array}\right.
$$

with $R e[-]$ the Reynolds number, and $w[\mathrm{~m}]$ the wall roughness, a parameter describing the roughness of the conduit walls. The different representations of $f$ describe laminar flow $\left(f_{l}\right)$ and different stages of turbulent flow $\left(f_{s}\right.$-smooth turbulence, $f_{t}$-transitional turbulence, $f_{r}$-rough turbulence). For the latter, the largest value controls turbulent flow behaviour. Note that both Reynolds number and friction factor have to be calculated with a standard iterative procedure.

The friction factor depends on the dimensionless Reynolds number Re:

$R e=\frac{\rho_{w} Q}{\eta} \frac{d}{A}$

with $A\left[\mathrm{~m}^{2}\right]$ the cross-sectional area of the conduit, $\rho_{w}\left[\mathrm{~kg} / \mathrm{m}^{3}\right]$ the fluid density, and $\eta[\mathrm{Pa}$ s] fluid viscosity. If the Reynolds number is below a certain threshold $\left(R e_{c} \sim 2200\right)$, flow in the conduit is laminar, above the threshold flow becomes turbulent.

Thus, depending on the flow regime, we arrive at a linear relation between hydraulic head drop and flow, describing laminar flow, and a quadratic relation, representing turbulent flow conditions.

The flowrate depends strongly on the conduit width (power-law of the order 3-4). The change in conduit width can be described (e.g. Kaufmann et al. 2014):

$\frac{d\left(t_{i+1}\right)-d\left(t_{i}\right)}{\Delta t}=\frac{m_{\text {rock }}}{\rho_{\text {rock }}} F(c)$

with $t_{i}$ and $t_{i+1}[\mathrm{~s}]$ two consecutive time steps, $F\left[\mathrm{~mol} / \mathrm{m}^{2} / \mathrm{s}\right]$ the calcium flux rate, $m_{\text {rock }}[\mathrm{kg} / \mathrm{mol}]$ the atomic mass of the dissolved rock, $\rho_{\text {rock }}\left[\mathrm{kg} / \mathrm{m}^{3}\right]$ the density of the dissolved rock, and $\Delta t=t_{i+1}-t_{i}[\mathrm{~s}]$. Note that $d(t=0)=d_{0}$ is the initial width of the conduit. The change in conduit width therefore depends on the calcium flux rate, with
$F>0$ describing enlargement of the conduit size by removing material from the conduit walls, and $F<0$ reduction of the conduit width by precipitating material on the conduit walls. The calcium flux rate itself is a function of the calcium concentration $c\left[\mathrm{~mol} / \mathrm{m}^{3}\right]$ in the conduit. During dissolution, $\mathrm{c}$ will increase along the conduit because of the removal of soluble rock from the conduit walls, until $c$ reaches the calcium equilibrium concentration $c_{e q}\left[\mathrm{~mol} / \mathrm{m}^{3}\right]$.

The change in calcium concentration along the conduit is calculated as (e.g. Dreybrodt et al., 2005)

$\frac{c\left(x_{i+1}\right)-c\left(x_{i}\right)}{\Delta x_{i}}=\frac{P(x)}{Q} F(c)$

with $x_{i}$ and $x_{i+1}[\mathrm{~m}]$ two neighbouring points along the conduit, $\Delta x=x_{i+1}-x_{i}, F(\mathrm{x})\left[\mathrm{mol} / \mathrm{m}^{2} / \mathrm{s}\right]$ the calcium flux rate, and $P(\mathrm{x})[\mathrm{m}]$ the perimeter of the conduit. Note that $c\left(x_{0}\right)=c_{\text {in }}$ is the input calcium concentration $c_{\text {in }}\left[\mathrm{mol} / \mathrm{m}^{3}\right]$ entering the conduit.

\section{CHEMICAL PROPERTIES}

The dissolution or precipitation of material from a conduit in soluble rock depends on the amount of soluble material that can be dissolved from the rock wall into the solution flowing through the conduit. Depending on the type of soluble rock, the equilibrium concentration of the dissolved species is a function of several properties.

We will focus on gypsum $\left(\mathrm{CaSO}_{4} \cdot 2 \mathrm{H}_{2} \mathrm{O}\right)$, anhydrite $\left(\mathrm{CaSO}_{4}\right)$, and limestone $\left(\mathrm{CaCO}_{3}\right)$ as soluble rock types. The chemical reactions for these different soluble rocks in an aqueous solution can be described through the following set of reactions (e.g. Duan \& Li 2008; Li \& Duan 2011):

$$
\begin{aligned}
& \mathrm{H}_{2} \mathrm{O} \rightleftharpoons \mathrm{H}^{+}+\mathrm{OH}^{-} \\
& \mathrm{H}_{2} \mathrm{O}+\mathrm{CO}_{2} \rightleftharpoons \mathrm{H}_{2} \mathrm{CO}_{3} \\
& \mathrm{H}_{2} \mathrm{CO}_{3} \rightleftharpoons \mathrm{H}^{+}+\mathrm{HCO}_{3} \\
& \mathrm{HCO}_{3}^{-} \rightleftharpoons \mathrm{H}^{+}+\mathrm{CO}_{3}{ }^{2-} \\
& \mathrm{CaSO}_{4} \cdot 2 \mathrm{H}_{2} \mathrm{O} \rightleftharpoons \mathrm{Ca}^{2+}+\mathrm{SO}_{4}{ }^{2-}+2 \mathrm{H}_{2} \mathrm{O} \\
& \mathrm{CaSO}_{4}+\mathrm{H}_{2} \mathrm{O} \rightleftharpoons \mathrm{Ca}^{2+}+\mathrm{SO}_{4}{ }^{2-}+\mathrm{H}_{2} \mathrm{O} \\
& \mathrm{CaCO}_{3}+\mathrm{H}_{2} \mathrm{O} \rightleftharpoons \mathrm{Ca}^{2+}+\mathrm{CO}_{3}{ }^{2-}+\mathrm{H}_{2} \mathrm{O} \\
& \mathrm{CaCO}_{3}+\mathrm{H}^{+} \rightleftharpoons \mathrm{Ca}^{2+}+\mathrm{HCO}_{3}^{-} \\
& \mathrm{CaCO}_{3}+\mathrm{H}_{2} \mathrm{CO}_{3} \rightleftharpoons \mathrm{Ca}^{2+}+2 \mathrm{HCO}_{3}^{-}
\end{aligned}
$$

The first reaction describes the dissociation of water, the second the solution of carbon dioxide $\left(\mathrm{CO}_{2}\right)$ in water, the next two ones the dissociation of carbonic acid, and the remaining equations the solution of gypsum, anhydrite and limestone, respectively.

All of the above equations can be described as equilibrium reactions with their respective mass action coefficients, $K_{i}$. The calcium equilibrium concentration for the soluble rock types can be derived as approximate function to excellent accuracy (e.g. Dreybrodt 1988): 


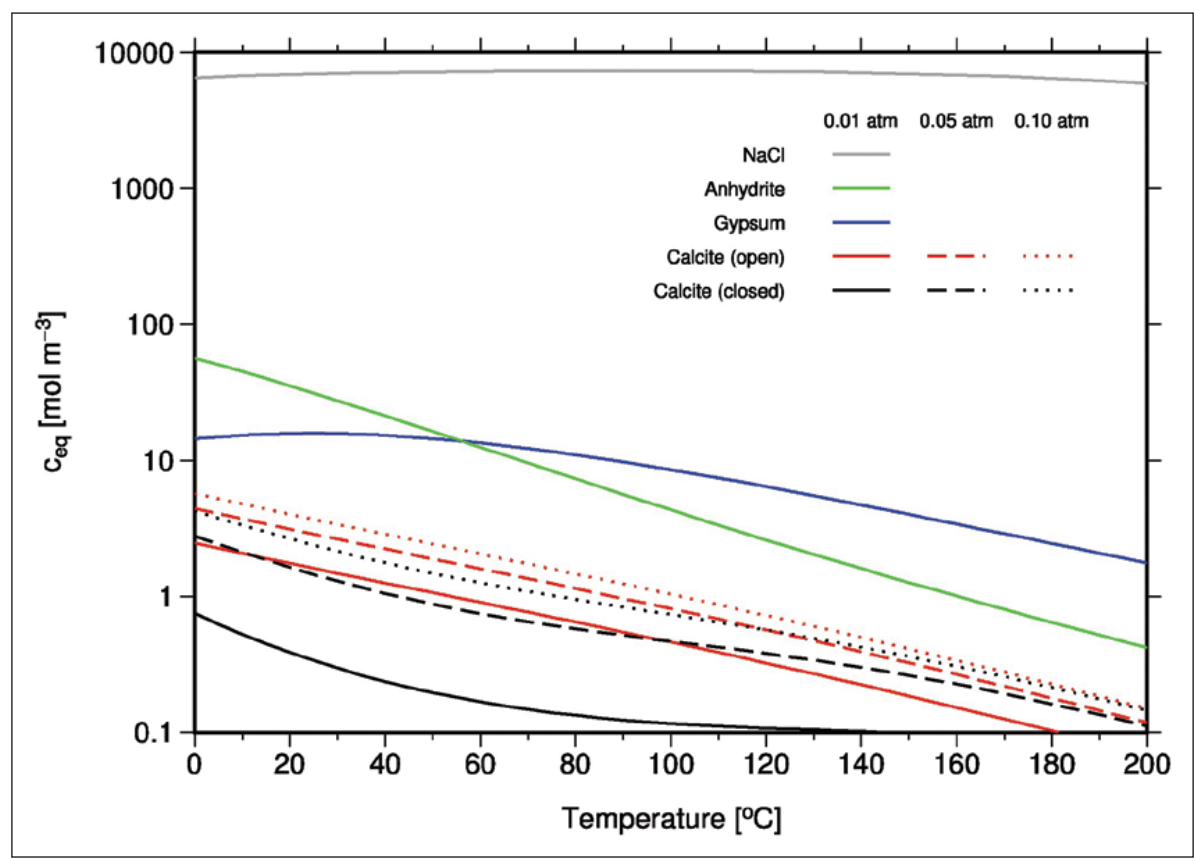

Fig. 2: Calcium equilibrium concentration as a function of temperature. Shown are curves for limestone $\left(\mathrm{CaCO}_{3}\right)$, gypsum $\left(\mathrm{CaSO}_{4} \cdot \mathrm{H}_{2} \mathrm{O}\right)$, anhydrite $\left(\mathrm{CaSO}_{4}\right)$, and halite $(\mathrm{NaCl})$. For limestone, the calcium equilibrium concentration is shown for three values of partial carbon-dioxide pressures and for open- and closed-system conditions.

$$
\begin{aligned}
& c_{e q}=\sqrt[2]{\frac{K_{A}}{\gamma_{\mathrm{Ca}^{2+} \gamma_{\mathrm{SO}_{4}^{2-}}}}} \text {, Anhydrite } \\
& c_{\text {eq }}=\sqrt[2]{\frac{K_{G}}{\gamma_{\mathrm{Ca}^{2+} \gamma_{\mathrm{SO}_{4}^{2-}}}}, \text { Gypsum }} \\
& c_{e q}=\sqrt[3]{\frac{K_{1} K_{\mathrm{C}} K_{\mathrm{H}}}{4 \mathrm{~K}_{2} \gamma_{\mathrm{Ca}^{2+}} \gamma_{\mathrm{HCO}_{3}^{-}}^{2}} p_{\mathrm{CO}_{2}}} \text { Calcite }
\end{aligned}
$$

with $K_{A}(T, z)$ (Blount \& Dickson 1973) the equilibrium constant for the dissolution of anhydrite, $K_{G}(T, z)$ (Blount \& Dickson 1973) the equilibrium constant for the dissolution of gypsum, $K_{H}(T, z)$ (Weiss 1974) the equilibrium constant for the dissolution of atmospheric carbon dioxide into water (Henry's law constant), $K_{0}(T, z)$ (Wissbrun et al. 1954) the equilibrium constant for the reaction of water and carbon dioxide to carbonic acid, $K_{1}(T, z)$ and $K_{2}(T, z)$ (Millero 1979; Mehrbach et al. 1973) the equilibrium constants for the dissociation of carbonic acid into bicarbonate, carbonate, and hydrogen, $K_{\mathrm{C}}(T, z)$ (Mucci $1983)$ the equilibrium constant for dissolved calcite, $\gamma_{\mathrm{Ca}_{2}+}$, $\gamma_{\mathrm{SO}_{4}^{2-}}$ and $\gamma_{\mathrm{HCO}_{3}^{-}}$the activity coefficients for calcium, sulfate and bicarbonate, $p_{\mathrm{CO}_{2}}$ [atm] the carbon-dioxide partial pressure, and $T\left[{ }^{\circ} \mathrm{C}\right]$ the temperature of the solution. Our analytical expressions compare well with the calculation of the calcium equilibrium concentration derived for the full electro-neutrality condition, which we verified by comparing our $c_{e q}$ to results obtained from PHREEQC (Parkhurst \& Appelo 2013).

For limestone, (7) is valid for the open system, in which the solution is in contact with the atmosphere, and carbon dioxide will be replenished by further solution of $\mathrm{CO}_{2}$ from the atmosphere. However, most conduit enlargement takes place under closed-system conditions, and here the $\mathrm{CO}_{2}$ is consumed and thus decreases with dissolution. In this case, the carbon- dioxide partial pressure is (Dreybrodt 1988):

$p_{\mathrm{CO}_{2}}=p_{C O_{2}}^{a t m}-\frac{c_{e q}}{K_{H}\left(1+\frac{1}{K_{0}}\right)}$

with $p^{a t m}$ [atm] the initial carbon-dioxide partial pressure obtained in the atmosphere and the soil.

The calcium equilibrium concentrations for limestone, gypsum, and anhydrite are shown in Fig. 2 as functions of temperature $T\left[{ }^{\circ} \mathrm{C}\right]$, and carbon- dioxide pressure $\mathrm{p}_{\mathrm{CO}_{2}}$ [atm] for the case of limestone. Note the large difference in $c_{\text {eq }}$ between limestone $c_{e q} \sim 1-5 \mathrm{~mol} / \mathrm{m}^{3}$, gypsum $c_{e q} \sim 15 \mathrm{~mol} / \mathrm{m}^{3}$, and anhydrite $c_{e q} \sim 40 \mathrm{~mol} / \mathrm{m}^{3}$. Also note that $c_{\text {eq }}$ for both limestone and anhydrite is a retrograde function of temperature, while for gypsum the temperature relation is prograde for temperatures below $30{ }^{\circ} \mathrm{C}$, retrograde above that temperature (see Fig. 2).

The calcium flux rate describes flux of dissolved species from and to rock surface per unit area and per time. It is controlled by several potentially rate-limiting processes on the bedrock surface, e.g. the surface reaction at the mineral surface and the transport of the dissolved species in the solution. Flux rates have been measured experimentally for limestone (e.g. Plummer et al. 1978; Svensson \& Dreybrodt 1992; Eisenlohr et al. 1999), and for gypsum and anhydrite (e.g. James \& Lupton 1978; Gobran \& Miyamoto 1985; Lebedev \& Lekhov 1990; Jeschke et al. 2001; Jeschke 2002), and for limestone have 

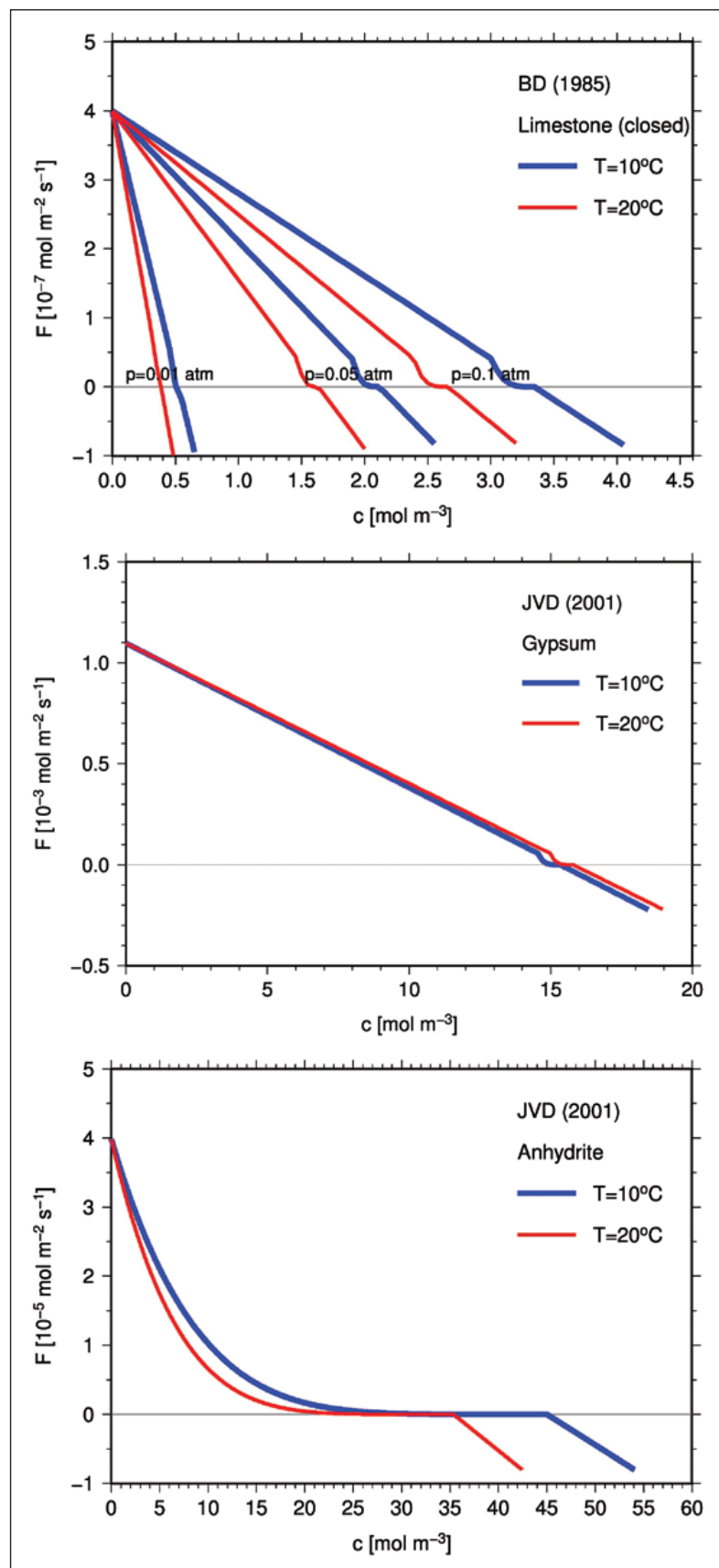

Fig. 3: Calcium flux rates as a function of calcium concentration for different soluble rocks. Curves are shown for two different temperatures and in the case of limestone also for three different partial carbon-dioxide pressures. Top: limestone, middle: gypsum, bottom: anhydrite.

been predicted numerically (e.g. Buhmann \& Dreybrodt 1985a,b; Dreybrodt \& Kaufmann 2007; Kaufmann et al. 2010). Flux rates $F\left[\mathrm{~mol} / \mathrm{m}^{2} / \mathrm{s}\right]$ can be described as a piece-wise function of the calcium concentration $c$ with respect to the calcium equilibrium concentration $c_{e q}$ (e.g. Palmer 1991)
$F=k_{i}\left(1-\frac{c}{c_{e q}}\right)^{n_{i}}$

with $k_{i}\left[\mathrm{~mol} / \mathrm{m}^{2} / \mathrm{s}\right]$ a rate coefficient, $c\left[\mathrm{~mol} / \mathrm{m}^{3}\right]$ the actual calcium concentration, $c_{e q}\left[\mathrm{~mol} / \mathrm{m}^{3}\right]$ the calcium equilibrium concentration, and $n_{i}[-]$ a power-law exponent. The rate coefficient depends on both surface-controlled rates and diffusion-controlled rates:

$k_{i}=\frac{k_{i}^{S} k_{i}^{D}}{k_{i}^{S}+k_{i}^{D}}$

with $k_{i}^{S}\left[\mathrm{~mol} / \mathrm{m}^{2} / \mathrm{s}\right]$ the surface-controlled rate coefficient, and with $k_{i}^{D}=2 D_{c e} / d\left[\mathrm{~mol} / \mathrm{m}^{2} / \mathrm{s}\right]$ the diffusion-controlled rate coefficient, and $D\left[\mathrm{~m}^{2} / \mathrm{s}\right]$ the diffusion coefficient. For a summary of coefficients see Tab. 1 .

Tab. 1: Parameter values for soluble rock chemistry.

\begin{tabular}{|c|c|c|c|c|}
\hline Limestone & Atomic mass & $m_{\text {Rock }}$ & {$[\mathrm{kg} / \mathrm{mol}]$} & 0.100 \\
\hline & Density & $\rho_{\text {Rock }}$ & {$\left[\mathrm{kg} / \mathrm{m}^{3}\right]$} & 2600 \\
\hline & Rate constant $^{1}$ & $k_{1}$ & {$\left[\mathrm{~mol} / \mathrm{m}^{2} / \mathrm{s}\right]$} & $4 \times 10^{-7}$ \\
\hline & Rate constant & $k_{2}=k_{1}\left(1-c_{s}\right)^{n-n 2}$ & & \\
\hline & Rate exponent ${ }^{1}$ & $n_{1}$ & {$[-]$} & 1 \\
\hline & Rate exponent ${ }^{1}$ & $n_{2}$ & {$[-]$} & 4 \\
\hline & Switch $^{1}$ & $c_{s}$ & {$[-]$} & 0.90 \\
\hline \multirow[t]{4}{*}{ Anhydrite } & Atomic mass & $m_{\text {Rock }}$ & {$[\mathrm{kg} / \mathrm{mol}]$} & 0.136 \\
\hline & Density & $\rho_{\text {Rock }}$ & {$\left[\mathrm{kg} / \mathrm{m}^{3}\right]$} & 2900 \\
\hline & Rate constant ${ }^{2}$ & $k_{1}$ & {$\left[\mathrm{~mol} / \mathrm{m}_{2} / \mathrm{s}\right]$} & $4 \times 10^{-5}$ \\
\hline & Rate exponent ${ }^{2}$ & $n_{1}$ & {$[-]$} & 5.4 \\
\hline \multirow[t]{7}{*}{ Gypsum } & Atomic mass & $m_{\text {Rock }}$ & {$[\mathrm{kg} / \mathrm{mol}]$} & 0.172 \\
\hline & Density & $\rho_{\text {Rock }}$ & {$\left[\mathrm{kg} / \mathrm{m}^{3}\right]$} & 2200 \\
\hline & Rate constant ${ }^{3}$ & $k_{1}$ & {$\left[\mathrm{~mol} / \mathrm{m}^{2} / \mathrm{s}\right]$} & $1.1 \times 10^{-3}$ \\
\hline & Rate constant & $k_{2}=k_{1}\left(1-c_{5}\right)^{n-n 2}$ & & \\
\hline & Rate exponent ${ }^{3}$ & $n_{1}$ & {$[-]$} & 1 \\
\hline & Rate exponent ${ }^{3}$ & $n_{2}$ & {$[-]$} & 4.5 \\
\hline & Switch'1 & $c_{s}$ & {$[-]$} & 0.95 \\
\hline
\end{tabular}

${ }^{1}$ Buhmann et al. (1985)

${ }^{2}$ Jeschke (2002)

${ }^{3}$ Jeschke et al. (2001)

The calcium flux rates for limestone, gypsum, and anhydrite are shown in Fig. 3 as a function of calcium concentration $\mathrm{c}$ for different temperatures $\mathrm{T}$ and carbondioxide pressures $\mathrm{P}_{\mathrm{CO}_{2}}$ in the case of limestone. For both limestone and gypsum, the flux rates for dissolution are characterised by a linear decrease with increasing calcium concentration, until a material-dependent threshold $\left(c_{s}\right)$ is reached. From then on, the flux rates decrease following a power law, thus are much slower (Svensson \& Dreybrodt 1992; Eisenlohr et al. 1999; Buhmann \& 
Dreybrodt 1985a,b). The reason for these non-linear flux rates at high calcium concentrations is the accumulation of impurities, which originate from insoluble material in the soluble host rock (e.g. clay). Note that for anhydrite, the flux rate is non-linear over the entire range for dissolution, which results in drastically different behaviour, as we will see later.

Once the calcium concentration $\mathrm{c}$ passes the calcium equilibrium concentration $\mathrm{c}_{\mathrm{eq}}$, precipitation starts. Here, experimental data are scarce, and only the precipitation rates for limestone are based on laboratory work (Buhmann \& Dreybrodt 1985b; Dreybrodt \& Buhmann 1991; Dreybrodt et al. 1997). For precipitation rates of anhydrite and gypsum, we assumed a linear relation, but we also discuss potential non-linearities later. The linear constant for precipitation is the negative of $k_{1}$ for the specified rock.

\section{DEPTH DEPENDENCE}

The material parameters density, gravity, and viscosity are functions of several variables, e.g. temperature and water pressure, which will be parameterised as depth $z[\mathrm{~m}]$. While we can safely neglect the depth dependence of the gravitational acceleration over the depth range of even deep karst aquifers, temperature, hydrostatic and lithostatic pressure, density, and viscosity have to be parameterised according to the increase in depth:

$T(z)=T_{0}+\left(\frac{d T}{d z}\right)_{\text {geotherm }} z$

$p(w)=\rho_{w} g z$

$p_{l}(w)=\rho_{l} g z$

$\rho(z)=\rho_{0}\left[1-\alpha T(z)+\kappa_{T} p_{w}(z)\right]$

$\log \frac{\eta(z)}{\eta_{0}}=\frac{20-T}{96+T}\left[a_{0}+a_{1}(20-T)+a_{2}(20-T)^{2}+a_{3}(20-T)^{3}\right]$

with $T_{0}\left[{ }^{\circ} \mathrm{C}\right]$ the annually-averaged surface temperature, $(\mathrm{dT} / \mathrm{dz})_{\text {geotherm }}\left[{ }^{\circ} \mathrm{C} / \mathrm{m}\right]$ the geothermal gradient, with $\rho_{w}\left[\mathrm{~kg} / \mathrm{m}^{3}\right]$ the density of water, and $\rho_{l}\left[\mathrm{~kg} / \mathrm{m}^{3}\right]$ the density

Tab. 2: Parameter values for depth dependences of material properties.

\begin{tabular}{l|l|l}
\hline Geothermal gradient & $(d T / d z)_{\text {geotherm }}$ & $25^{\circ} \mathrm{C} / \mathrm{km}$ \\
\hline Thermal expansivity & $a$ & \\
\hline Compressibility & $\kappa_{\tau}$ & \\
\hline Viscosity & $\eta_{0}$ & $1.002 \times 10^{-3} \mathrm{~Pa} \mathrm{~s}$ \\
\hline & $a_{0}$ & 1.2378 \\
\hline & $a_{1}$ & $1.303 \times 10^{-3}$ \\
\hline & $a_{2}$ & $3.060 \times 10^{-6}$ \\
\hline & $a_{3}$ & $2.550 \times 10^{-8}$ \\
\hline & &
\end{tabular}

of rock, $\rho_{0}\left[\mathrm{~kg} / \mathrm{m}^{3}\right]$ the respective surface values, $g\left[\mathrm{~m} / \mathrm{s}^{2}\right]$ the gravitational attraction, $\alpha[1 / \mathrm{K}]$ the thermal expansivity of water (e.g. Jones \& Schoonover, 2002), $\kappa_{T}[1 / \mathrm{Pa}]$ the compressibility of water (e.g. Jones \& Schoonover 2002), $\eta[\mathrm{Pas}]$ the viscosity of water, $\eta_{0}[\mathrm{Pas}]$ the reference value for the viscosity of water at surface pressure and $25{ }^{\circ} \mathrm{C}$, $a_{i}$ polynomial coefficients for the viscosity (Kestin et al. 1978). Note that of course the water pressure depends on the induced flow, but for the depth-dependence of parameter values we use the hydrostatic pressure as simplification, which is justified, as induced pressure is smaller than increase in hydrostatic pressure. A more detailed discussion of the depth-dependent properties can be found in Kaufmann et al. (2014).

\section{MODEL IMPLEMENTATION}

The equations developed above have been implemented by the authors into a simple numerical code in Fortran 90. The program performs the following steps:

Parameter values are read (e.g. $d_{0}, l, z_{\max }, \Delta h, c_{i n}$, $\left.p_{\mathrm{CO}_{2}}, T_{0},(\mathrm{dT} / \mathrm{dz})_{\text {geotherm }}\right)$.

- The conduit is discretised intonx-elements, and the conduit path is assigned, following $z=z_{\max }\left[1-((2 x / \mathrm{l})-1)^{2}\right]$, assigning a parabolic flow path for depth. Note that spatial discretisation for the conduit is controlled by the change of calcium concentration along the conduit (see Dreybrodt et al. (2005), for a discussion of concentration increments).

- A time stepping routine then calculates the evolution of the conduit. For each time step, a parcel of water enters the first conduit element with the pre-defined calcium input concentration $c_{i n}$. Then for each sub-sequent conduit element, temperature, density, viscosity, and conduit width are calculated for the given depth according to (11). Time steps are chosen small enough to ensure convergence of results.

- The flow rate in the conduit element is calculated, based on (1) and depending on the flow regime, using the equivalent resistance formula for conduit elements

Tab. 3: Parameter values for standard model.

\begin{tabular}{l|l|l}
\hline Conduit length & $I$ & $2000 \mathrm{~m}$ \\
\hline Conduit radius & $d$ & $0.5 \mathrm{~mm}$ \\
\hline Max. conduit depth & $z_{\max }$ & $0 \mathrm{~m}$ \\
\hline Head drop & $\Delta h$ & $10 \mathrm{~m}$ \\
\hline Surface temperature & $T_{0}$ & $10^{\circ} \mathrm{C}$ \\
\hline CO2-Pressure & $p_{\mathrm{CO}_{2}}$ & $0.05 \mathrm{~atm}$ \\
\hline Calcium input concentration & $C_{\text {in }}$ & $0 \mathrm{~mol} / \mathrm{m}^{3}$ \\
\hline Wall roughness & $W$ & $0.00002 \mathrm{~m}$ \\
\hline Diffusion coefficient & $D$ & $10^{-9} \mathrm{~m}^{2} / \mathrm{s}$ \\
\hline
\end{tabular}


in series (see Groves \& Howard (1994a) and Howard and Groves (1995), for a discussion of the equivalent resistance).

- With these parameters, the calcium concentration (5), the calcium equilibrium concentration $c_{e q}(7)$ and the calcium flux rate $\mathrm{F}(9)$ are calculated in each conduit element.
- Based on the flux rate and the time step $\Delta t$, the new width of the conduit element is calculated according to (4).

- Finally, the calcium concentration is changed according to (5), and then passed to the next conduit element.

We now have assembled all relevant information on flow, evolution, and depth dependence of the hydraulic and chemical parameter values.

\section{RESULTS \& DISCUSSION}

In this section, we discuss results from numerical solutions of the flow and evolution equations for a single circular fracture. We start with a shallow conduit resembling a water-table cave and three different soluble rock types, limestone, gypsum, and anhydrite. We then allow the conduit to penetrate deeper into the aquifer, resembling a bathy-phreatic flow path. Then we proceed with a combined dissolution-precipitation of material in these different soluble rocks. Finally, we describe a limestone conduit coated with gypsum to discuss the inception hypothesis.

\section{DISSOLUTION IN SHALLOW SETTINGS}

We first discuss the evolution of a single conduit in different soluble rocks and for three soluble rock types: This first case we term water-table conduit, as it is horizontal and close to the surface. The conduit considered has a length of $l=2000 \mathrm{~m}$ and an initial width of $d_{0}=0.5 \mathrm{~mm}$ for the water-table conduit. Flow is driven from left to right, with a hydraulic head drop of $\Delta h=10 \mathrm{~m}$, and the calcium concentration of solution entering the conduit is $c_{i n}=0 \mathrm{~mol} / \mathrm{m}^{3}$. As climatic variables, we assume a temperature of $\mathrm{T}=10{ }^{\circ} \mathrm{C}$ and a carbon-dioxide pressure of $p_{\mathrm{CO}_{2}}=0.05 \mathrm{~atm}$.

\section{Limestone}

The temporal evolution of a conduit in limestone is shown in Fig. 4 (top). For the given temperature and carbon-dioxide pressure, the calcium equilibrium concentration is around $c_{e q} \simeq 2.11 \mathrm{~mol} / \mathrm{m}^{3}$. The conduit evolves as a typical conduit in soluble rocks often discussed in the literature as classical breakthrough (e.g. Palmer 1991; Dreybrodt 1990; Dreybrodt et al. 2005; Kaufmann 2002): The initial enlargement is focussed to the very first part of the conduit, where a typical funnel shape evolves (red solid lines in Fig. 4 top). The calcium concentration increases rapidly over a distance of just a few meters to attain values around $90 \%$ of the equilibrium value. Most of the con- duit thus only slowly enlarges due to the high-order kinetic rate law active here. With time, the entrance funnel migrates further into the conduit, and first-order kinetics moves forward. Once the first-order kinetics reaches the exit of the conduit, the conduit starts enlarging almost uniformly over its entire length (blue dashed lines in Fig. 4 top), and flow has become turbulent. The transition from high-order to first-order kinetics at the exit of the conduit characterises this two-fold evolution, and the time first-order kinetics reaches the exit is termed breakthrough time $\left(\mathrm{T}_{\mathrm{B}}\right)$ in the literature (e.g. Dreybrodt 1996). This breakthrough event occurs at around $T_{B} \sim 140,000$ years in the case of the water-table conduit in limestone.

\section{Gypsum}

The temporal evolution of a conduit in gypsum is shown in Fig. 5 (top). For the given temperature, the calcium equilibrium concentration is around $c_{e q} \simeq 15.35 \mathrm{~mol} / \mathrm{m}^{3}$. The evolution of the water-table conduit is essentially the same as in the case of limestone: A preferential enlargement to a funnel shape at the entrance during the early phase (red solid lines in Fig. 5 top), with first-order kinetics only active in the first few tens of meters. The highorder kinetics active along the entire remaining part of the conduit ensures a bottleneck for flow, as the conduit width close to the exit remains low and thus flow out is limited. Once the first-order kinetics migrates through the conduit and reaches the exit, the breakthrough event occurs, and from then on the conduit enlarges at constant pace (blue dashed lines in Fig. 5 top) under turbulent flow conditions. Note, however, that the breakthrough time for the water-table conduit in gypsum is with $T_{B} \sim 24,000$ years an order of magnitude smaller than in the case of limestone!

\section{Anhydrite}

The temporal evolution of a conduit in anhydrite is shown in Fig. 6 (top). For the given temperature, the calcium 


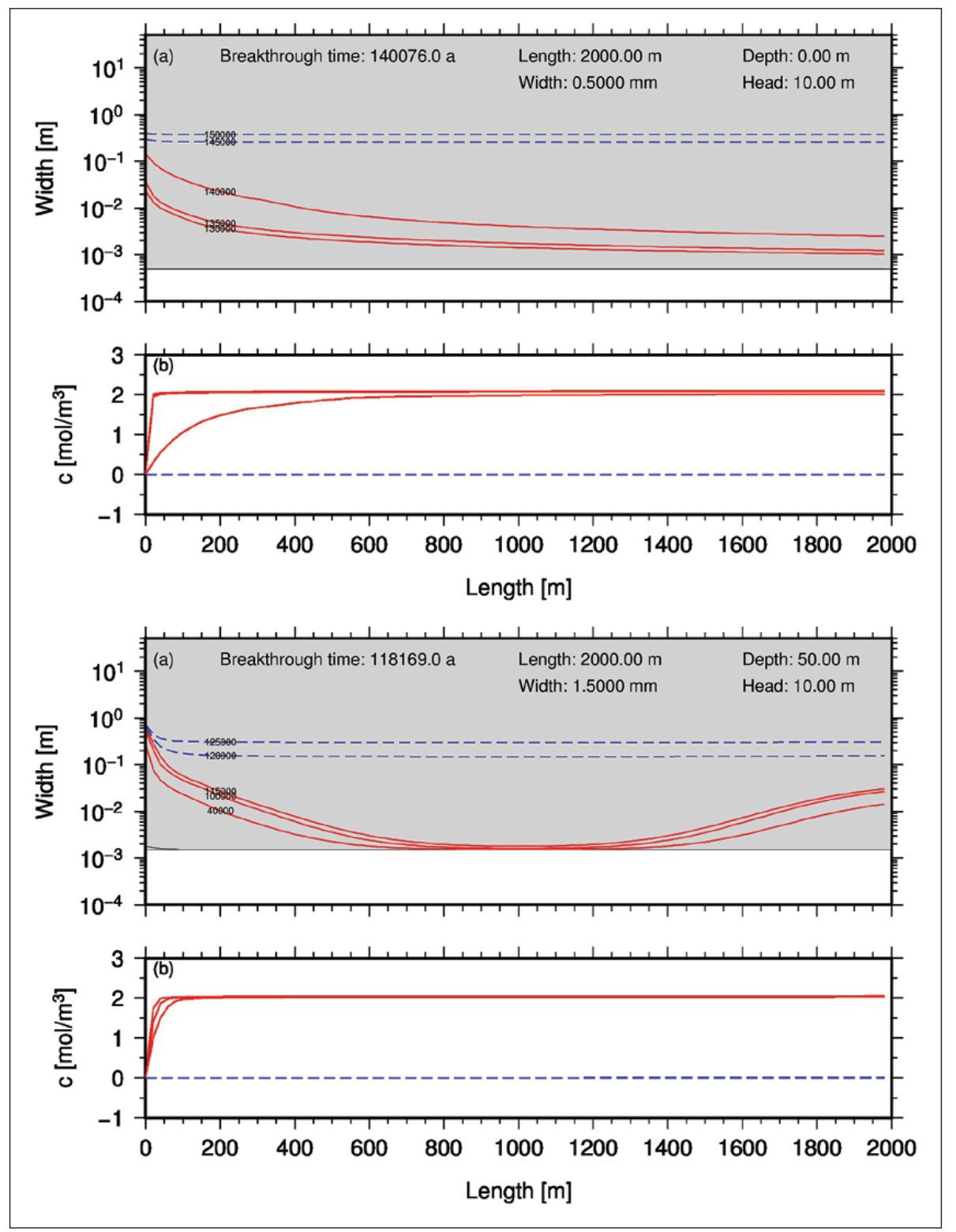

Fig. 4: Evolution of single limestone conduit with time. Shown are conduit width and calcium concentration for several time steps (see notation on lines in years). Red lines indicate period before breakthrough, blue lines after breakthrough, and the flow condition is either laminar (solid lines) or turbulent (dashed lines). Top: Limestone water-table conduit. Bottom: Limestone deepphreatic conduit.

equilibrium concentration is around $c_{e q} \simeq 45 \mathrm{~mol} / \mathrm{m}^{3}$. At a first glance, the evolution of the conduit width is not too different from the two previous cases. Before breakthrough, a funnel shape at the entrance part evolves, and the remainder of the conduit widens only very slowly (red solid lines in Fig. 6 top). Once the breakthrough event occurs, the conduit grows at almost uniform pace (blue dashed lines) under turbulent flow conditions. However, two points are very different: (i) The breakthrough time is $T_{B} \sim 500$ years, which is very short. (ii) The calcium concentration profiles along the conduit differ from the previous two cases; while calcium concentration increases rapidly over the first few tens of meters, it remains below $90 \%$ of $c_{\text {e }}$ for the remainder of the conduit for all times before breakthrough. This significant undersaturation is a result of the anhydrite calcium flux rate (see Fig. 3), which is non-linear for the entire dissolution branch. No first-order kinetics is present here, and thus the high-order kinetics keep the undersaturation with respect to calcium over the entire conduit length, and is therefore responsible for the fast evolution.

\section{DISSOLUTION IN DEEP SETTINGS}

In this second part of the results section, we discuss the deep-phreatic conduit, which extends to considerable depth $z_{\max }$. This depth-extent of the conduit causes the solution to be subject to elevated pressure and temperature conditions, thus changes in the chemistry of the solution. 


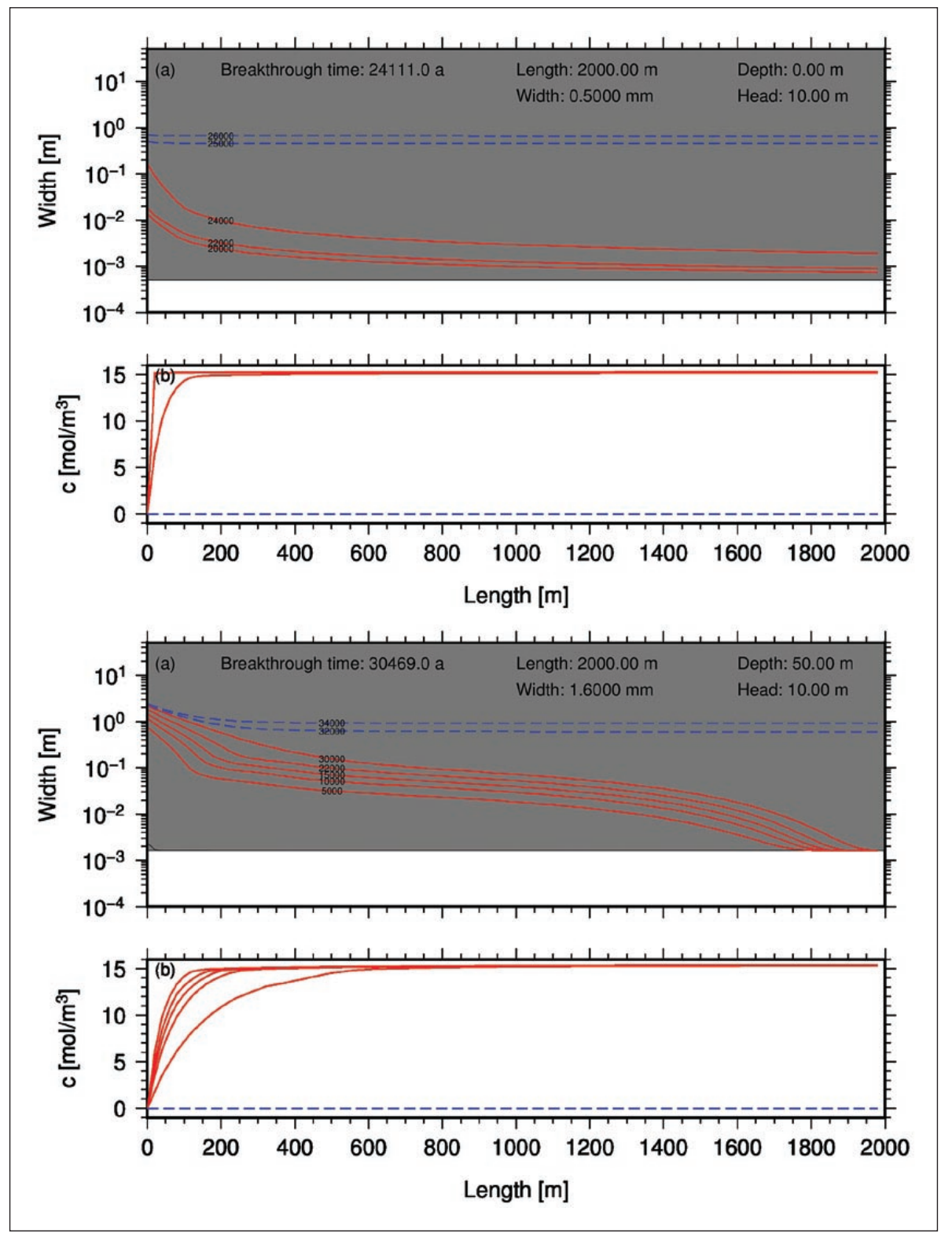

Fig. 5: As Fig. 4, but for gypsum conduit.

\section{Limestone}

This deep-phreatic conduit (Fig. 4 bottom) evolves in a very different manner than the water-table conduit. During the early evolution the entrance part is enlarged to a funnel shape as before, but with increasing depth the conduit evolution becomes inhibited. The reason for the slow enlargement in greater depth is the decrease in calcium equilibrium concentration: At $50 \mathrm{~m}$ depth, the temperature is $T(50 \mathrm{~m})=11.25^{\circ} \mathrm{C}$, hydraulic pressure is $p_{w}(50 \mathrm{~m})=0.5 \mathrm{MPa}$, and thus the calcium equilibrium concentration reduces to $c_{e q}(50$ $\mathrm{m}) \simeq 2.05 \mathrm{~mol} / \mathrm{m}^{3}$, which is around $3 \%$ lower than the surface value. This lower calcium equilibrium concentration results in slower enlargement with depth, while the ascending part of the conduit (last half of the conduit) enlarges more, as here the calcium equilibrium concentration increases again and allows for faster dissolution (red solid lines). With time, firstorder kinetics will also be established in this case, and from then on a breakthrough event occurs, and after that the conduit grows with almost uniform enlargement rates. Note that we increased the initial conduit width to $d_{i}=1.5 \mathrm{~mm}$ for the deep-phreatic conduit to achieve a breakthrough time comparable to the watertable conduit (see Kaufmann et al. 2014, for further details).

Note that for a significant depth extent of the deepphreatic conduit, the elevated temperatures in that depth may result in a reduced calcium equilibrium concentration below the actual calcium concentration, thus pre- 


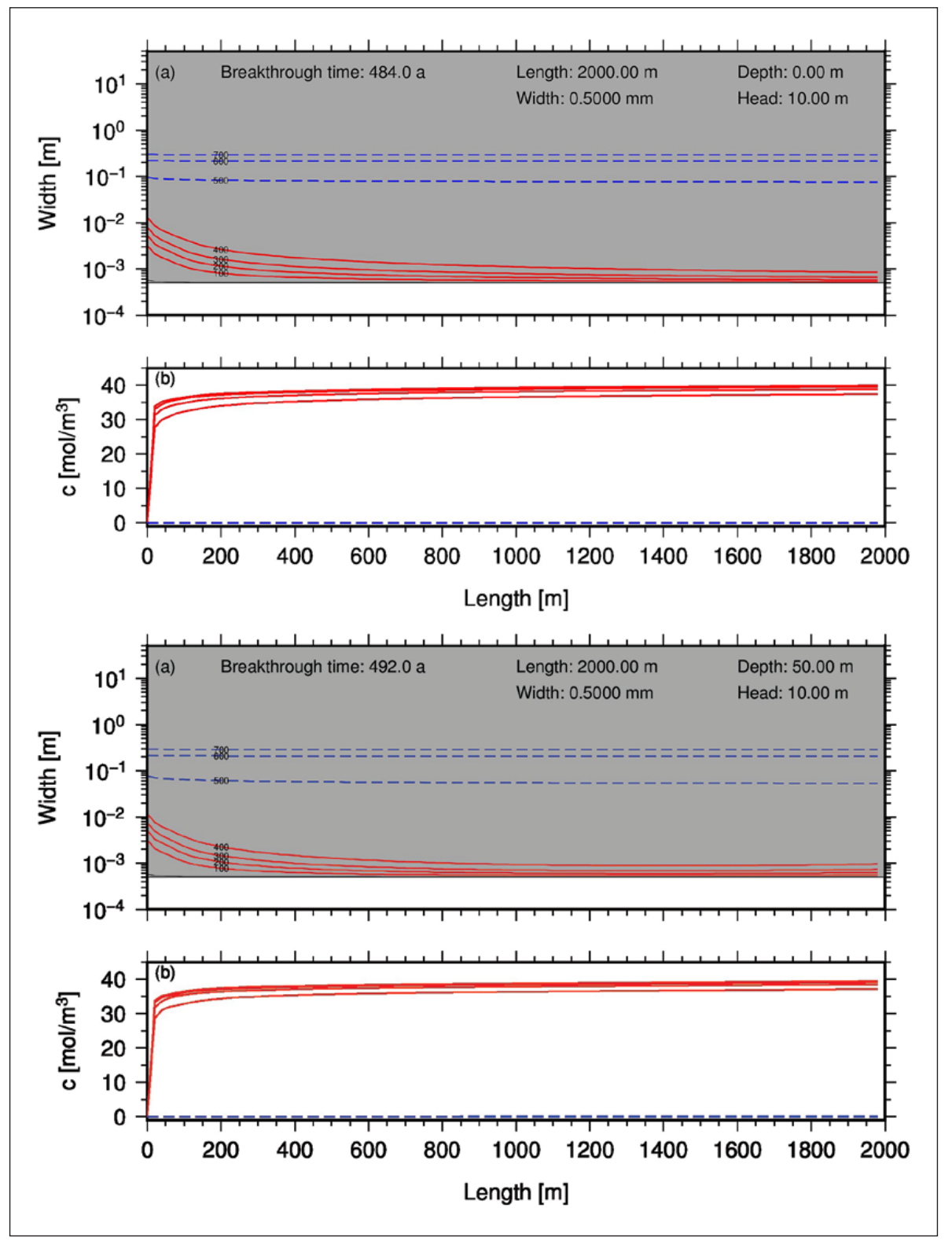

Fig. 6: As Fig. 4, but for anhydrite conduit.

cipitation would occur and the conduit will clog. We will discuss this clogging process later.

\section{Gypsum}

For the deep-phreatic conduit in gypsum we again have increased the initial conduit width to $d_{i n i}=1.6 \mathrm{~mm}$ to obtain a similar breakthrough time $\left(T_{B} \sim 30,000\right.$ years $)$. The evolution of this deep-phreatic conduit is, however, very different from the evolution of a similar conduit in limestone (Fig. 5 bottom): Before breakthrough, we can distinguish three different regions. (i) An area close to the entrance of the conduit (100-200 m into the fracture), where the first-order kinetics results in a funnel-shape enlargement of the entrance part. (ii) An area of rela- tively uniform growth (200-1500 m into the conduit), which has already enlarged to the centimeter-scale before breakthrough. (iii) The area around the exit of the conduit, which is still small, enlarging at a very slow pace and thus resulting in the bottleneck for flow responsible for keeping the calcium concentration in the high-order regime over large parts of the conduit. The reason for the different evolution before breakthrough is the prograde dependence of the calcium equilibrium concentration for gypsum for temperatures below $30{ }^{\circ} \mathrm{C}$ : At $50 \mathrm{~m}$ depth, the calcium equilibrium concentration increases to $c_{e q}(30 \mathrm{~m}) \simeq 15.61 \mathrm{~mol} / \mathrm{m}^{3}$, which is around $2 \%$ larger than the surface value. Thus while the majority of the conduit experiences high-order kinetics before break- 


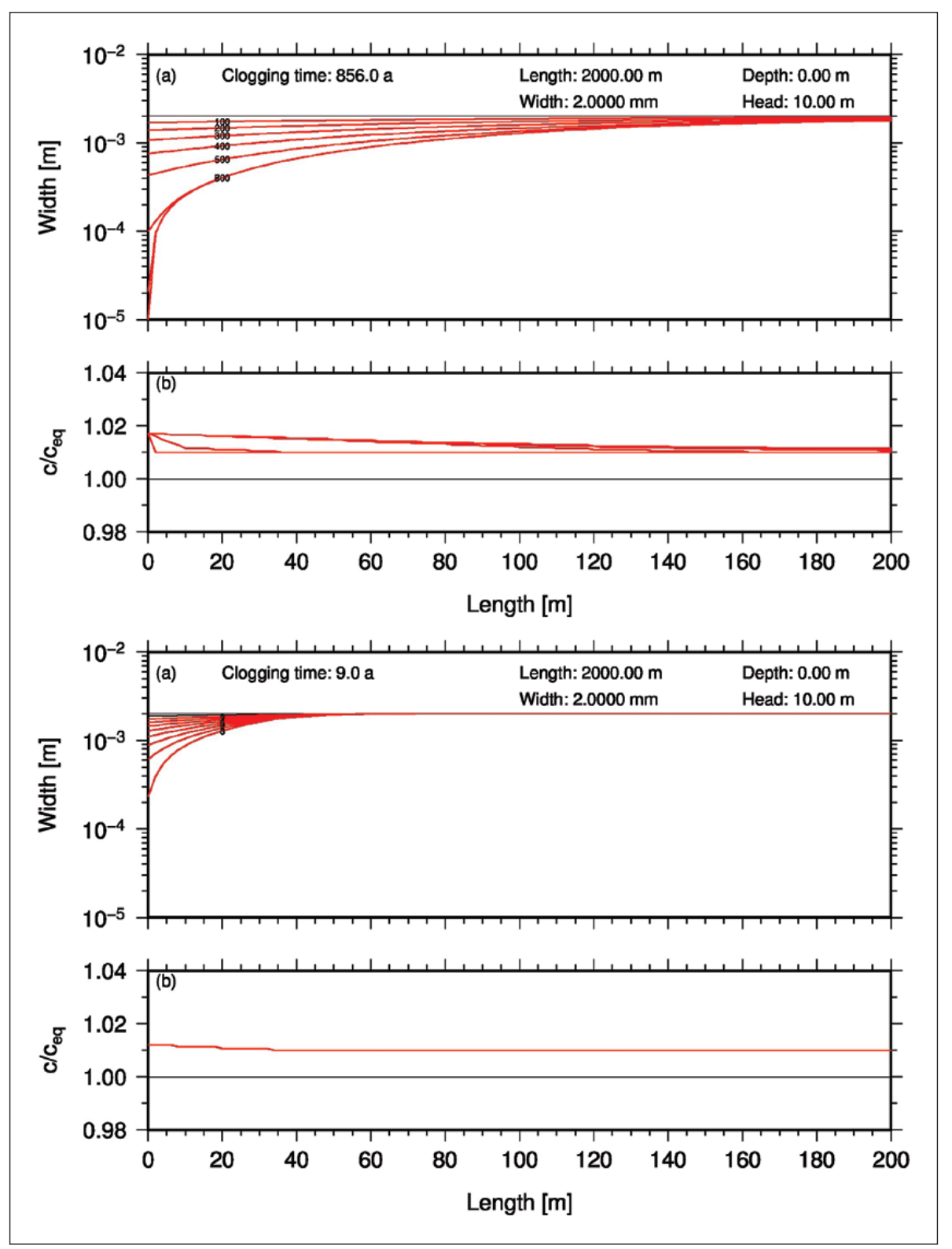

Fig. 7: Clogging of single conduit with time by precipitation. Note that only the first $200 \mathrm{~m}$ of the conduits is shown. Evolution of width and calcium concentration for limestone conduit (top) and for gypsum conduit (bottom).

through, in the lower parts of the conduit the solution is slightly more aggressive due to the increase in $\mathrm{c}_{\mathrm{eq}}$. This is responsible for the widespread enlargement in the deeper parts of the deep-phreatic conduit.

After breakthrough is established, the entire conduit enlarges at almost constant pace (blue dashed lines in Fig. 5 bottom) under turbulent flow conditions.

\section{Anhydrite}

The above mentioned significant undersaturation with respect to calcium also changes the evolution for an anhydrite conduit reaching deeper into the subsurface. Here, no real difference from the water-table conduit evolution is observed, and breakthrough times for both flow paths are very similar. The drop in calcium equilibrium concentration due to the elevated temperature and water pressure at $30 \mathrm{~m}$ depth resulting in a calcium equilibrium concentration of $c_{e q}(30 \mathrm{~m}) \sim 44.08 \mathrm{~mol} / \mathrm{m}^{3}$ and thus a reduction of around $2 \%$ relative to the surface value has no significant effect on the strong undersaturation in the conduit, the high-order kinetics of the calcium flux rate for anhydrite dominates the evolution by far.

We note, however, that at this point we neglected the precipitation of gypsum, which will occur in the anhydrite conduit due to the differences in calcium equilibrium concentration, which will of course change the conduit evolution. We come back to this point in the next section. 


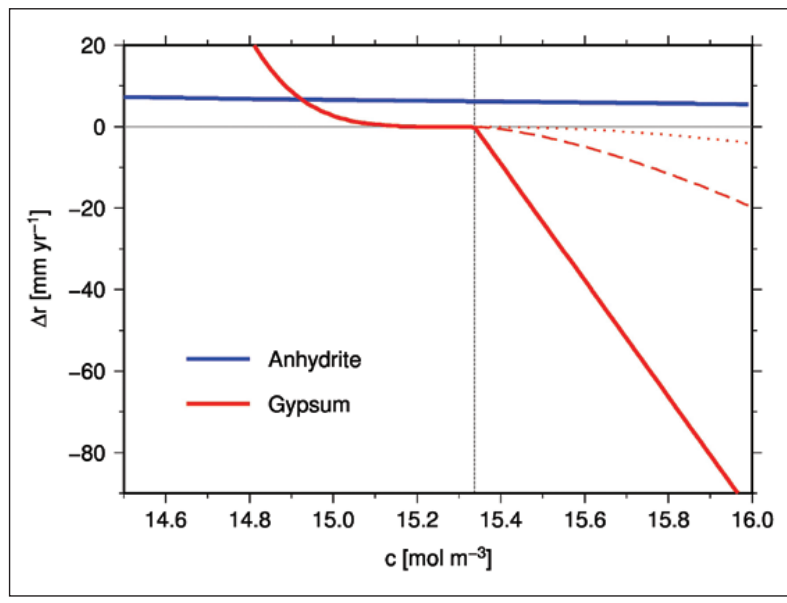

Fig. 8: Wall retreat $\Delta r$ as a function of calcium concentration $c$ for anhydrite (blue solid line) and gypsum (red lines). For gypsum, different rate-equation exponents for precipitation are shown ( $n_{1}=1.0$, solid, $n_{1}=1.5$, dashed, $n_{1}=2.0$, dotted $)$. The dashed grey line marks the calcium equilibrium concentration for gypsum at $T=10^{\circ} \mathrm{C}$.

\section{DISSOLUTION AND PRECIPITATION IN SHALLOW SETTINGS}

In this third part of the results section, we will look into the problem of clogging the conduit by precipitation of the corresponding mineral. We will focus first on limestone and gypsum as soluble rocks, and treat anhydrite separately because of the precipitation of gypsum in an anhydrite conduit.

We argue that the conduit is now subject to inflow with supersaturated solution with respect to calcium. An example would be water passing through a gypsum layer, being saturated with respect to calcium, then flowing into a limestone conduit. We restructure the conduit by addressing a length of $l=2000 \mathrm{~m}$ and an initial width of $d_{i n i}=2.0 \mathrm{~mm}$, and applying the hydraulic head difference of $\Delta h=10 \mathrm{~m}$.

\section{Limestone}

We first consider limestone as conduit material, and provide a solution to the conduit, which is slightly supersaturated with respect to calcium: $c_{\text {in }}=2.13 \mathrm{~mol} / \mathrm{m}^{3}$, $c_{e q}=2.12 \mathrm{~mol} / \mathrm{m}^{3}$. In Fig. 7, the evolution of this conduit is shown. The conduit width starts reducing along the entrance section of the conduit, as here the (small) super-saturation is largest. The deposition becomes smaller along the conduit, as the excess calcium in the solution is consumed. An inverse funnel shape appears, as more and more calcite is deposited, and after $T_{C} \sim 856$ years the entrance part of the conduit is closed ( $T_{C}$-clogging time) and flow through the conduit stops. Note that still the majority of the initial void volume is present, as the conduit has only been sealed off by a plug.

\section{Gypsum}

We now make up a conduit of gypsum, and feed a solution with $c_{i n}=15.37 \mathrm{~mol} / \mathrm{m}^{3}$, thus slightly supersaturated when compared to the calcium equilibrium concentration of $c_{e q}=15.35 \mathrm{~mol} / \mathrm{m}^{3}$. This conduit closes essentially in the same manner as the limestone conduit, but just in a fraction of the time ( $\mathrm{T}_{\mathrm{C}} \sim 9$ years).

\section{Anhydrite}

In section 4.1, we have seen that an anhydrite conduit evolves very fast due to the non-linear kinetics of the anhydrite dissolution. However, once the calcium concentration in the anhydrite conduit reaches the calcium equilibrium concentration of gypsum $\left(\sim 15 \mathrm{~mol} / \mathrm{m}^{3}\right)$, gypsum starts to precipitate:

$$
\begin{aligned}
\mathrm{CaSO}_{4}+2 \mathrm{H}_{2} \mathrm{O} & \rightleftharpoons \mathrm{Ca}^{2+}+\mathrm{SO}_{4}{ }^{2-}+2 \mathrm{H}_{2} \mathrm{O} \\
& \rightleftharpoons \mathrm{CaSO}_{4} \cdot 2 \mathrm{H}_{2} \mathrm{O}
\end{aligned}
$$

We have seen in section 4.2 that a gypsum conduit can become clogged by precipitation of gypsum in only a couple of years, even for small super-saturation with respect to gypsum.

In Fig. 8, the change in conduit width (wall retreat) is shown for a system at $\mathrm{T}=10^{\circ} \mathrm{C}$ and both anhydrite and gypsum. The calcium concentration range chosen focuses around the calcium equilibrium concentration for gypsum. While the enlargement of a conduit in anhydrite with a chemical composition around $\mathrm{c} \sim 15 \mathrm{~mol} / \mathrm{m}^{3}$ is with $\Delta r \simeq 6-8 \mathrm{~mm} / \mathrm{yr}$ rather constant, the situation for precipitation of gypsum dramatically changes the evolution. Once the calcium equilibrium concentration for gypsum $\left(c_{\text {eq }}^{\text {gypsum }}=15.3 \mathrm{~mol} / \mathrm{m}^{3}\right)$ is passed, gypsum will start to precipitate. If the calcium concentration in the conduit exceeds $c_{\text {eq }}^{\text {gypsum }}$ just slightly, the deposition rate of gypsum quickly reaches values larger than $\Delta r>-10 \mathrm{~mm} / \mathrm{yr}$, thus outpacing the removal of anhydrite by far. The conduit will clog very soon along the entrance part, and flow is inhibited. The reason for this quick clogging of course is the difference in atomic mass and density for anhydrite and gypsum, which translates into these different retreat rates according to (4).

As we have stated in section 3 , the precipitation flux rates for both anhydrite and gypsum are not well known. We therefore plotted the deposition rate for gypsum also for non-linear flux rate laws $\left(n_{1}=1.5\right.$, dashed red line; $n_{1}=2$, dotted red line). We observe a fairly substantial impact of the non-linearity to gypsum precipitation, which, however, will still outpace the dissolution of anhydrite. 


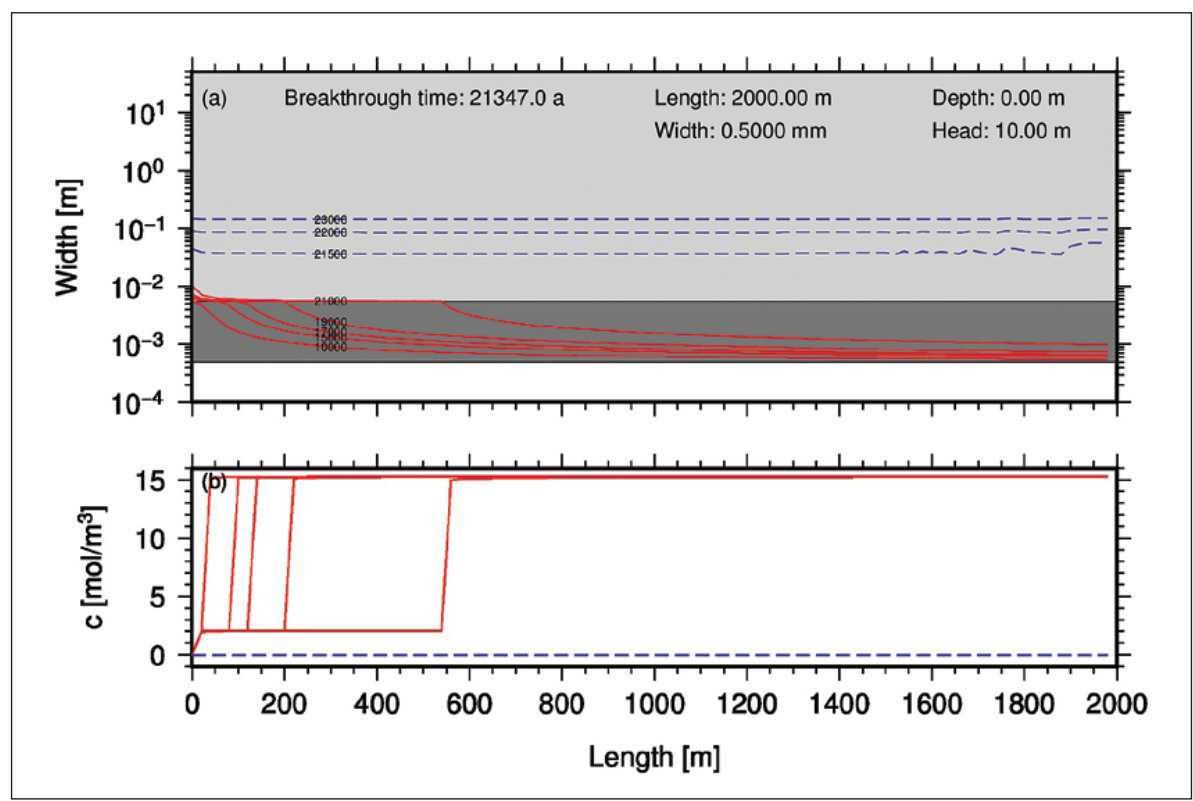

Fig. 9: Evolution of limestone conduit with gypsum coating.

We speculate that this behaviour will have an impact on problems as during the drilling of the hydrothermal drill hole in Staufen (Sass \& Burbaum 2010), which connected two aquifers and caused flow of under-saturated solution through an anhydrite lens. As the anhydrite gets dissolved, the calcium concentration reaches the threshold, when gypsum starts to precipitate. If the gypsum precipitate is able to get firmly attached to the fracture wall, clogging of the anhydrite fracture can occur. However, in the case of very high flow-rate conditions, the gypsum precipitate might be flushed out, before it is attached to the fracture wall, thus the fracture remains open.

\section{Multi-material conduit}

In this last section, we pick up the discussion on inception horizons from the introduction. There are numerous observations of faults and bedding planes in limestone more favorable to karstification than others (e.g. Filipponi et al. 2009; Plan et al. 2009, and references therein). Often, these inception horizons have been covered with pyrite $\left(\mathrm{FeS}_{2}\right.$ ), which then oxidized according to (Ritsema \& Groenenberg 1993):

$$
\begin{gathered}
4 \mathrm{FeS}_{2}+15 \mathrm{O}_{2}+14 \mathrm{H}_{2} \mathrm{O} \\
\rightleftharpoons \quad 4 \mathrm{Fe}(\mathrm{OH})_{3}+16 \mathrm{H}^{+}+8 \mathrm{SO}_{4}{ }^{2-} \\
\mathrm{CaCO}_{3}+2 \mathrm{H}^{+}+\mathrm{SO}_{4}{ }^{2-}+\mathrm{H}_{2} \mathrm{O} \\
\rightleftharpoons \quad \mathrm{CaSO}_{4} \cdot 2 \mathrm{H}_{2} \mathrm{O}+\mathrm{CO}_{2}
\end{gathered}
$$

The first reaction describes the oxidation of pyrite. The latter reaction occurs at the boundary of the fracture wall, where the sulfate reacts with calcite to form gypsum. This gypsum, which covers the fracture, can then readily dissolve and provides a rapid initial enlargement of the limestone fracture. Note that the carbon dioxide released can then be dissolved in water and thus increase the calcium equilibrium concentration, water becomes again undersaturated with respect to calcite and can dissolve additional limestone.

We show such an example in Fig. 9. Here, a limestone conduit with a length of $l=2000 \mathrm{~m}$ and an initial width of $d_{i n i}=0.5 \mathrm{~mm}$ is covered with a gypsum layer of $5 \mathrm{~mm}$ thickness. Flow is driven from left to right by the hydraulic head difference of $\Delta h=10 \mathrm{~m}$, the incoming solution is aggressive $\left(c_{i n}=0 \mathrm{~mol} / \mathrm{m}^{3}\right)$.

The conduit experiences a two-stage evolution. First, the gypsum starts dissolving up to its saturation $\left(c_{e q}^{\text {gypsum }} \simeq 15 \mathrm{~mol} / \mathrm{m}^{3}\right)$. The entrance enlarges as funnel shape, the remainder of the conduit only slowly enlarges. After 10,000 years, the gypsum along the entrance section of the conduit is gone, the conduit here starts evolving by dissolving limestone with its lower saturation $\left(c_{\text {eq }}^{\text {calcite }} \simeq 2 \mathrm{~mol} / \mathrm{m}^{3}\right)$. As the solution saturated with respect to limestone is still aggressive with respect to the gypsum, the fast gypsum dissolution is pushed further into the conduit.

This scenario is similar to the limited dissolution proposed by Romanov et al. (2010) and Gabrovšek and Stepišnik (2011). If there is limitation of soluble material in the direction perpendicular to flow, enlargement becomes more uniform along the entire conduit. In our case, after 10,000 years the gypsum vanishes along the entire conduit, flow rate increases and dissolution of the exposed limestone then accelerates.

When we compare breakthrough times of this gypsum/limestone conduit $\left(T_{B} \sim 21,000\right.$ years $)$ to that of a similar conduit only composed of limestone 
( $T_{B} \sim 140,000$ years, see Fig. 4 ), we find an acceleration of evolution by an order of magnitude. This faster evolution can explain the importance of an inception horizon, which is chemically distinct from the other conduit by the gypsum cover. The inception horizon evolves way faster than the surrounding conduit and thus captures flow and provides a preferential pathway.

The limited dissolution due to the thin thickness of the gypsum cover plays an important role. We have reduced for the example conduit discussed above the thickness of the gypsum cover from 5 to $1 \mathrm{~mm}$, and breakthrough time becomes even shorter ( $T_{B} \sim 13,000$ years). Thus two mechanisms can be identified as important for preferential karstification along inception horizons: The faster dissolution of the gypsum precipitate, and the more uniform enlargement due to the limited dissolution effect.

We can of course also speculate about the opposite effect: A limestone conduit coated with gypsum can clog, if the gypsum layer has a non-uniform thickness. If a thinner gypsum coating within the conduit is removed first and the limestone exposed in that part, the solution arriving is significantly supersaturated with respect to limestone, and limestone will precipitate and can eventually clog flow of the entire conduit.

\section{CONCLUSIONS}

We have developed a formal framework for describing the evolution of a single isolated conduit in a soluble rock, which can be enlarged by dissolution of the rock, and which can clog as a result of precipitation of a mineral in solution. The single conduit can consist of limestone, gypsum, or anhydrite, or a combination of these soluble rock types.

As stated in Introduction, we defined three key points for our analysis, which we will answer now:

i Shallow and deep flow and evolution in conduits for different soluble rock types (limestone, gypsum, anhydrite):

A first result, already established in the literature, is the strong dependence of the evolution time on the type of soluble rock considered: While the enlargement of conduits in limestone under natural hydraulic conditions can be between 1000 and 10000 years, conduits in anhydrite and gypsum evolve much faster, on timescales of $10-100$ years.

Deeper flow paths as considered in the bathyphreatic evolution of caves depend on the change of environmental parameters with depth: Temperature, water and rock pressure generally increase with depth, changing hydraulic properties (e.g. water viscosity), but also the chemical properties (e.g. calcium equilibrium concentration). Here, the retro-grade dependence of calcium equilibrium concentration on temperature for limestone and anhydrite are responsible for a reduction of enlargement with depth, thus bathyphreatic flow paths evolve slower, when compared to water-table flow paths. For gypsum, however, the pro-grade dependence of calcium equilibrium concentration on temperature (at least for temperatures below $30{ }^{\circ} \mathrm{C}$ ) does not inhibit evolution with depth.

ii Precipitation in conduits:

Once solution becomes supersaturated with respect to calcium, either through changes in temperature and/ or water pressure or evaporation, the conduit can clog due to precipitation. As the precipitation of soluble rock is largest along the inflow part of the fracture, clogging creates a plug inhibiting flow, but keeps large parts of the conduit further downstream still open.

iii Evolution of conduits composed of several soluble rock layers:

If a conduit consists of more than one material, the evolution becomes more complicated. In our example of a limestone conduit coated with gypsum (e.g. from the conversion of pyrite into gypsum) evolves more quickly, when compared to a pure limestone conduit. Here, the gypsum coating is quickly removed along the entire conduit, thus the remaining limestone part has a larger diameter, which for the ongoing evolution exerts a strong control on the time of evolution. 


\section{ACKNOWLEDGEMENTS}

We would like to thank two anonymous referees, whose comments improved the manuscript substantially. GK acknowledges funding from the DFG under research grant KA1723/6-2. This project has been carried out at the Karst Research Institute of Slovenia (ZRC SAZU) during a sabbatical stay of GK. Figures were prepared using GMT software (Wessel \& Smith 1998).

\section{REFERENCES}

Beek, W. J. \& K. M. K. Muttzall, 1975: Transport Phenomena.-John Wiley, London.

Blount, C. \& F. Dickso, 1973: Gypsum-anhydrite equilibria in systems $\mathrm{CaSO}_{4}-\mathrm{H}_{2} \mathrm{O}$ and $\mathrm{CaSO}_{4}-\mathrm{NaCl}-\mathrm{H}_{2} \mathrm{O}$. Am. Mineralogist, 58, 323-331.

Bretz, J. H., 1942: Vadose and phreatic features of limestone caves.-. J. Geology 50, 675-811. DOI: https:// doi.org/10.1086/625074.

Buhmann, D. \& W. Dreybrodt, 1985a: The kinetics of calcite dissolution and precipitation in geologically relevant situations of karst areas. 1. Open system.- Chem. Geol., 48, 189-211. DOI: https://doi. org/10.1016/0009-2541(85)90046-4.

Buhmann, D. \& W. Dreybrodt, 1985b: The kinetics of calcite dissolution and precipitation in geologically relevant situations of karst areas. 2. Closed system.- Chem. Geol., 53, 109-124. DOI: https://doi. org/10.1016/0009-2541(85)90024-5.

Davis, W. M., 1930: Origin of limestone caverns.- Geol. Soc. Am. Bull., 41, 475-628. DOI: https://doi.org/ 10.1130/GSAB-43-663.

Dreybrodt, W., 1988: Processes in Karst Systems. Springer, 278 pp., Berlin.

Dreybrodt, W., 1990: The role of dissolution kinetics in the development of karst aquifers in limestone: a model simulation of karst evolution.- J. Geol., 98, 5, 639-655. DOI: https://doi.org/10.1086/629431.

Dreybrodt, W., 1996: Principles of early development of karst conduits under natural and man-made conditions revealed by mathematical analysis of numerical models.- Water Resour. Res., 32, 9, 2923-2935, https://doi.org/10.1029/96WR01332.

Dreybrodt, W. \& D. Buhmann, 1991. A mass transfer model for dissolution and precipitation of calcite from solutions in turbulent motion.- Chem. Geol., 90, 107-122. DOI: https://doi.org/10.1016/00092541(91)90037-R.
Dreybrodt, W., Eisenlohr, L., Madry, B. \& S. Ringer, 1997: Precipitation kinetics of calcite in the system $\mathrm{CaCO}_{3}-\mathrm{H}_{2} \mathrm{O}-\mathrm{CO}_{2}$ : The conversion to $\mathrm{CO}_{2}$ by the slow process $\mathrm{H}^{+}+\mathrm{HCO}^{-3} \rightarrow \mathrm{CO}_{2}+\mathrm{H}_{2} \mathrm{O}$ as a rate limiting step.- Geochem. Cosmochem. Acta, 61, 18, 3897-3904. DOI: https://doi.org/10.1016/S00167037(97)00201-9.

Dreybrodt, W., Gabrovšek, F. \& D. Romanov, 2005: Processes of Speleogenesis: A modeling approach. Založba ZRC, 375 pp., Ljubljana.

Dreybrodt, W. \& G. Kaufmann, 2007: Physics and chemistry of dissolution on subaerially exposed soluble rocks by flowing water films.- Acta Carsologica, 36, 3, 357-367. DOI: https://dx.doi.org/10.3986/ ac.v36i3.169.

Duan, Z. \& D. Li, 2008. An improved model for the calculation of $\mathrm{CO} 2$ solubility in aqueous solutions containing $\mathrm{Na}^{+}, \mathrm{K}^{+}, \mathrm{Ca}^{2+}, \mathrm{Mg}^{2+}, \mathrm{Cl}^{-}$, and $\mathrm{SO}^{2-}$.- $\mathrm{Geo}-$ chem. Cosmochem. Acta, 72, 5128-5145. DOI: https://doi.org/10.1016/j.marchem.2005.09.001.

Eisenlohr, L., Meteva, K., Gabrovšek, F. \& W. Dreybrodt, 1999: The inhibiting action of intrinsic impurities in natural calcium carbonate minerals to their dissolution kinetics in aqueous $\mathrm{H}_{2} \mathrm{O}-\mathrm{CO}_{2}$ solutions.- Geochim. Cosmochem. Acta, 63, 6, 989-1001. DOI: https://dx.doi.org/10.1016/S0016-7037(98)00301-9.

Filipponi, M. \& P.-Y. Jeannin, 2006: Is it possible to predict karstified horizons in tunneling?- Austrian Journal of Earth Sciences, 99, 24-30.

Filipponi, M., Jeannin, P. \& L. Tacher, 2009: Evidence of inception horizons in karst conduit networks.Geomorphology, 106, 86-99. DOI: https://doi.org/ 10.1016/j.geomorph.2008.09.010.

Ford, D. C. \& R.O. Ewers, 1978: The development of limestone cave systems in the dimensions of length and depth.- Can. J. Earth Sci., 15, 1783-1798. DOI: http://dx.doi.org/10.5038/1827-806X.10.3.1.https:// doi.org/10.1139/e78-186. 
Gabrovšek, F. \& U. Stepišnik, 2011: On the formation of collapse dolines: A modeling perspective. Geomorphology, 134, 23-31. DOI: https://doi.org/10.1016/j. geomorph.2011.06.007.

Gobran, G. \& S. Miyamoto, 1985: Dissolution rates of gypsum in aqueous salt solutions.- Soil Science, 140, 2, 89-93. DOI: https://10.1097/00010694-198508000-00002.

Groves, C. G. \& A. D. Howard, 1994a. Minimum hydrochemical conditions allowing limestone cave development. Water Resour. Res. 30 (3), 607-615, https:// dx.doi.org/10.1029/93WR02945.

Groves, C. G. \& A.D. Howard, 1994b. Early development of karst systems 1. Preferential flow path enlargement under laminar flow. Water Resour. Res., 30, 10, 2837-2846. DOI: https://dx.doi. org/10.1029/94WR01964.

Howard, A. D. \& C.G. Groves, 1995. Early development of karst systems 2. Turbulent flow. Water Resour. Res., 31, 1, 19-26. DOI: https://dx.doi. org/10.1029/94WR01303

James, A. \& A.Lupton, 1978. Gypsum and anhydrite in foundations of hydraulic structures. Geotechnique, 28, 3, 249-272. DOI: https://doi.org/10.1680/ geot.1978.28.3.249.

Jeppson, R. W., 1976. Analysis of flow in pipe networks. Ann Arbor Sci. Pub., 164 pp., Ann Arbor.

Jeschke, A., Vosbeck, K. \& W. Dreybrod, 2001. Surface controlled dissolution rates of gypsum in aqueous solutions exhibit nonlinear dissolution rates. Geochem. Cosmochem. Acta, 65, 1, 27-34. DOI: https://doi.org/10.1016/S0016-7037(00)00510-X

Jeschke, A. A., 2002; Lösungskinetik von Gips und Anhydrit. Ph.D. thesis, Universität Bremen, Bremen, Germany.

Jones, F. \& R. Schoonove, 2002. Handbook of Mass Measurements. CRC Book, $336 \mathrm{pp}$.

Kaufmann, G., 2002: Karst conduit evolution. In: Gabrovšek, F. (Ed.), Evolution of Karst: From Prekarst to Cessation. Carsologica, ZRC SAZU, PostojnaLjubljana, pp. 327-338.

Kaufmann, G., Gabrovsek, F. \& D. Romanov, 2014: Deep conduit flow in karst aquifers revisited.- Water Resour. Res, 50, 6, 4821-4836. DOI: https://dx.doi. org/10.1002/2014WR015314.

Kaufmann, G., Romanov, D. \& T. Hiller, 2010: Modelling three-dimensional karst aquifer evolution using different matrix-flow components.- J. Hydrol., 388, 241-250. DOI: https://dx.doi.org/10.1016/j. jhydrol.2010.05.001.
Kestin, J., Sokolov, M. \& W. Wakeham, 1978: Viscosity of liquid water in the range $-8{ }^{\circ} \mathrm{C}$ to $150{ }^{\circ} \mathrm{C}$. J. Phys. Chem. Ref. Data, 7, 3, 941-948. DOI: https://dx.doi. org/10.1063/1.555581.

Lebedev, A. \& A. Lekhov, 1990: Dissolution kinetics of natural gypsum in water at $5-25{ }^{\circ} \mathrm{C}$.- Geochem. Int., 27, 85-94.

Li, J. \& Z. Duan, 2011: A thermodynamic model for the prediction of phase equilibria and speciation in the $\mathrm{H}_{2} \mathrm{O}-\mathrm{CO}_{2}-\mathrm{NaCl}-\mathrm{CaCO}_{3}-\mathrm{CaSO}_{4}$ system from 0 to $250{ }^{\circ} \mathrm{C}, 1$ to 1000 bar with $\mathrm{NaCl}$ concentrations up to halite saturation.-Geochem. Cosmochem. Acta, 75, 4351-4376. DOI: https://doi.org/10.1016/j.gca. 2011.05.019

Lowe, D., 1992: The origin of limestone caverns: an inception horizon hypothesis. Ph.D. thesis, Manchester Polytechnic, United Kingdom.

Lowe, D., 2000: Role of stratigraphic elements in speleogenesis: the speleo inception concept. In: Klimchouk, A., Ford, D., Palmer, A. \& W. Dreybrodt (Eds.), Speleogenesis, evolution of karst aquifers. National Speleological Society, Huntsville (Alabama), pp. 65-76.

Lubitz, C., Motagh, M., Wetzel, H.-U. \& H. Kaufmann, 2013: Remarkable urban uplift in Staufen im Breisgau, Germany: Observations from terrasar-x insar and leveling from 2008 to 2011.- Remote Sensing, 5, 3082-3100. DOI: https://dx.doi.org/10.3390/rs5063082 .

Mehrbach, C., Culberson, C.H.and Hawley, J. \& R. Pytkowicz, 1973: Measurement of the apparent dissociation constants of carbonic acid in seawater at atmospheric pressure.- Limnology and Oceanography, 18, 6, 897-907. DOI: https://dx.doi.org/10.4319/ lo.1973.18.6.0897.

Millero, F. J., 1979: The thermodynamics of the carbonate system in seawater.- Geochemica et Cosmochemica Acta 43, 1651-1661, https://dx. doi. org/10.1016/0016-7037(79)90184-4.

Mucci, A., 1983: The solubility of calcite and aragonite in seawater at various salinities, temperatures, and one atmosphere total pressure. -American Journal of Science, 283, 781-799. DOI: https://dx.doi. org/10.2475/ajs.283.7.780.

Palmer, A. N., 1991: Origin and morphology of limestone caves.- Geol. Soc. Am. Bull., 103, 1-21. DOI: https://doi.org/10.1130/0016-7606(1991)103\%3C0 001:OAMOLC\%3E2.3.CO;2. 
Parkhurst, D. \& C. Appelo, 2013: Description of input and examples for PHREEQC version 3 - A computer program for speciation, batch-reaction, onedimensional transport, and inverse geochemical calculations.- U.S. Geological Survey Techniques and Methods, Book 6, Chap. A43, 497 p., available online http://pubs.usgs.gov/tm/06/a43 (Accessed October $10^{\text {th }}, 2017$ )

Plan, L., Filipponi, M., Behm, M., Seebacher, R. \& P. Jeutter, 2009: Constraints on alpine speleogenesis from cave morphology - a case study from the eastern Totes Gebirge (Northern Calcareous Alps, Austria).- Geomorphology, 106, 118-129. DOI: https:// doi.org/10.1016/j.geomorph.2008.09.011.

Plummer, L. N., Wigley, T. M. L. \& D.L. Parkhurst, 1978: The kinetics of calcite dissolution in $\mathrm{CO}_{2}$-water systems at $5{ }^{\circ} \mathrm{C}$ to $60{ }^{\circ} \mathrm{C}$ and 0.0 to 1.0 atm $\mathrm{CO}_{2}$ - $^{-} \mathrm{Am}$. J. Sci., 278, 179-216. DOI: htpps://doi.org/ 10.2475/ ajs.278.2.179

Rhoades, R. \& N.M. Sinacori, 1941; Patterns of groundwater flow and solution.- J. Geology, 49, 785-794. DOI: https://doi.org/10.1086/625014.

Ritsema, C. \& J. Groenenberg, 1993: Pyrite oxidation, carbonate weathering, and gypsum formation in a drained potential acid sulfate soil.- Soil Science Society of America Journal, 57, 968-976. DOI:https://dl.sciencesocieties.org/publications/sssaj/abstracts/57/4/SS0570040968.

Romanov, D., Kaufmann, G. \& T. Hiller, 2010: Karstification of aquifers interspersed with non-soluble rocks: from basic principles towards case studies.- Eng. Geol., 116, 261-273. DOI: https://doi.org/10.1016/j. enggeo.2010.09.008.

Sass, I. \& U. Burbaum, 2010: Damage caused to the historic town of Staufen (Germany) caused by geothermal drillings through anhydrite-bearing formations.- Acta Carsologica, 39, 2, 233-245. DOI: http://dx.doi.org/10.3986/ac.v39i2.96.
Svensson, U. \& W. Dreybrodt, 1992: Dissolution kinetics of natural calcite minerals in $\mathrm{CO} 2$-water systems approaching calcite equilibrium. Chem. Geol., 100, 129-145. DOI: https://doi.org/10.1016/0009-2541(92)90106-F.

Swinnerton, A. C., 1932: The origin of limestone caverns.- Geol. Soc. Am. Bull., 34, 662-693. DOI: https://doi.org/10.1130/GSAB-43-663.

Szymczak, P. \& A. Ladd, 2006: A network model of channel competition in fracture dissolution.- Geophysical Research Letters, 33, L05401. DOI: https://doi. org/10.1029/2005GL025334.

Szymczak, P. \& A. Ladd, 2009. Wormhole formation in dissolving fractures.- J. Geophys. Res. M 114, B06203. DOI: https://doi.org/10.1029/2008JB006122.

Szymczak, P. \& A. Ladd, 2011: The initial stages of cave formation: Beyond the one-dimensional paradigm. Earth and Planetary Science Letters, 201, 424-432. DOI: https://doi.org/10.1016/j.epsl.2010.10.026.

Weiss, R. F., 1974: Carbon dioxide in water and seawater: the solubility of a non-ideal gas.- Marine Chemistry 2, 203-215, https://doi.org/10.1016/0304-4203(74)90015-2.

Wessel, P. \& W. H. F. Smith, 1998. New, improved version of generic mapping tools released.- EOS, 79, 579. DOI: https://doi.org/10.1029/98EO00426

Wissbrun, K., French, D. \& A. Patterson Jr., 1954: The true ionization constant of carbonic acid in aqueous solution from 5 to $45^{\circ}$.- J. Phys. Chem., 58, 9, 693695. DOI: htpps://doi.org/10.1021/j150519a004.

Worthington, S. R. H., 2001: Depth of conduit flow in unconfined carbonate aquifers.- Geology, 29, 4, 335-338. DOI: https://doi.org/10.1130/0091-7613(2001)029\%3C0335:DOCFIU\%3E2.0.CO;2. 